\title{
Kvakksalver fra landet
}

\author{
- To ganger har det skjedd at folk har sett meg inn i øynene og sagt: «Men Anders, kvinner er mer \\ kompliserte enn mark.» $\AA$, har jeg svart, det glemte de å si på doktorskolen i Oslo.
}

Anders Seim er vennligheten selv og svært beskjeden på egne vegne. Men han er ustoppelig når han får lov til å fortelle om prosjektene sine, da snakker han på inn- og utpust med innskutte bisetninger og større eller mindre digresjoner. Det kom en e-post dagen etter at vi hadde møttes: «Jeg tenker med bekymring på at jeg skravlet så fælt at du virket som du ikke fikk svar på en del av det du var i ferd med å spørre om.» - Stemmer det, svarte jeg, kan vi treffes igjen?

Han har fått en del overbærende blikk og kanskje en kaffe i kantinen når han har presentert sine ideer. Hvem er han som kommer her og kommer her og tror han kan redde verden - en kvakksalver fra landet? Men mange har måttet bite det i seg. Allmennlegen fra Nesodden har på høflig vis bitt seg fast i maktens buksebein og ikke gitt seg før han har fått gjennomslag for sine tanker. Slik har han bidratt til å gjøre verden til et litt bedre sted. Tusenvis av mennesker slipper å oppleve guineaorm, elefantsyke og fødselsfistel.

Han kommer fra et møblert hjem og vokste i hovedsak opp i USA, hvor faren jobbet innen shipping. Da han var åtte år, bestemte han seg for å bli lege. Gnisten ble tent da faren til en klassekamerat fortalte om jobben sin, og 15 år senere søkte unge Seim legestudiet i Oslo. Det ble allmennpraksis i Lier, og så Nesodden med legekontor i et lite hus på landet.

- Det var skikkelig family practice, kjøkkenbenken fungerte som laboratorium og ungene krabbet opp i fanget på de gamle damene på venteværelset, minnes han lattermildt.

Anders og kona Liv var enige om at de to barna burde lære seg skikkelig engelsk, for det kunne komme godt med senere i livet. Da han også fikk snusen i muligheten for å studere ett år ved Harvard, sendte han sporenstreks en søknad.

- Året på Harvard er et av de beste jeg har hatt. Eventyyyrlig flott, sier Seim, og skryter av miljøet og alle mulighetene som åpnet seg.

\section{Dumt og genialt}

Studiet resulterte i en Master of Public Health og ble et vendepunkt i karrieren. En studiekamerat tipset ham om en gjesteforelesning.

- Det var Don Hopkins fra Carter-senteret som snakket om utrydding av guineaorm. Metoden hadde vært kjent siden 1800- tallet, og nå som kopper omsider var erklært utryddet, forsøkte man å mobilisere politisk vilje til å utrydde guineaormen. Dum og uerfaren som jeg var, tenkte jeg at jeg kunne introdusere foreleseren for den norske FN-delegasjonen i New York. Jeg kjente ingen der, men jeg er jo norsk... Han skjønte nok at det var et tøvete forslag og ba meg heller forsøke å få noen fra Norge til å komme på et møte i Ghana, der tidligere USA-president Jimmy Carter også skulle være til stede. Carter-senteret har en ledende rolle i gjennomføringen av guineaormprosjektet. Jeg lyktes ikke med å rekruttere noen, så jeg dro selv, sier Seim.

Til stede var Verdens helseorganisasjon (WHO), UNICEF, Cartersenteret, 19 affiserte land - og Anders Seim.

Guineaorm er en parasitt og har mennesket som eneste vert. Den kommer inn i kroppen via drikkevann og ferdig utviklet tar den seg ut igjen gjennom huden. Den meterlange ormen bruker uker på å komme seg ut, og prosessen er svært smertefull. Det er lett å utrydde guineaorm. I teorien. Gi folk rent drikkevann. Hvis det ikke er rent, gi dem tøy å filtrere vannet med. Få de syke til å holde seg unna drikkevannskilden mens marken kommer ut, ellers finner den seg enkelt en ny vert. Men hvordan filtrere drikkevannet for folk under krig og på vandring i Afrika? Sugerør med filter var en like enkel som genial løsning. I 2001 initierte og organiserte Anders Seim et prosjekt som distribuerte ni millioner slike sugerør i Sudan. - Ni millioner! Det er et vanvittig tall som tilsvarer 1700 kilometer med små sugerør. Da vi begynte arbeidet, hadde 3,5 millioner mennesker guineaormsykdommen på verdensbasis. I år har det vært ca. 1 600. Vi nærmer oss!

To år etter sugerørsprosjektet bidro norske medisinstudenter gjennom sin humanitæraksjon MedHum (1). De sørget for behandlingsutstyr til alle affiserte landsbyer i Sudan, etterfylling året etter og ytterligere 450000 sugerørsfiltre.

- To kvinnelige medisinstudenter stilte til og med opp som frivillige langt inne i SørSudan, sier Seim, tydelig rørt og imponert.

\section{Katalysator for folkehelse}

Health \& Development International (HDI) er en bitteliten frivillig organisasjon med to personer på hovedkontoret. Anders Seim oppret- tet den i 1990. Organisasjoner flest konsentrerer seg gjerne om ett og ett geografisk område. - Vår tanke var å jobbe i 20 land i Afrika og litt inn i Asia. Så da ble det til at vi startet HDI som en egen organisasjon. - Eller du?

\section{- Eller.. Ja.}

HDI Norge og HDI USA har samme hovedkontor, på Svestad på Nesodden. De første ti årene holdt de til på et lite loftsrom over legekontoret på Fagerstrand - inntil Seim fant ut at han måtte velge fastlegejobben eller den internasjonale hobbyen. Begge jobbene ble større og større, han selv eldre og eldre, og han kjente at strikken nærmet seg bristepunktet.

- Savner du legejobben?

- Jeg syntes det var hyggelig å være doktor, men jeg savner ikke den konstant dårlige samvittigheten for at folk satt to timer på venteværelset. Det med tiden fikk jeg ikke helt til. Og så savner jeg ikke den tiltakende fornemmelsen av å drive pølsebod, der både pasienter og myndigheter skal ha «pølse med alt».

- Hvordan ser arbeidsdagen din ut nå?

- Høyst variert, ler Seim. - Jeg bruker mye tid foran PCen og i telefonen, og så reiser jeg to-tre uker av gangen. Da sitter jeg i bil og skramler bortover en vei som ikke finnes, eller venter under et tre mens noen reparerer et dekk, eller snakker med folk på kontorer og i stråtelt. Og så er det endeløse rapporter. En gang sendte jeg ni kilo med dokumenter med FedEx. Ni kilo!

Kona Liv, som er sykepleier, lærer og glasskunstner, hjelper til med regnskapene. Og mye annet. Pengene hun får for glasskunsten går uavkortet til HDI. De kommer godt med når $10 \%$ av alle midler som bevilges fra Norad må samles inn av HDI selv, fra norske givere. Den største utfordringen ved å drive en slik organisasjon er naturlig nok å få midler.

- Det har vært en betydelig utfordring. Enten det er det amerikanske utenriksdepartementet eller norske Norad så tror jeg det har lett for å bli sånn at de store ideene kommer fra toppen, og så blir de gjennomført. Makta rår. Jeg er ofte overrasket over hva som ser ut til å utløse midler og hvor tungt det kan være for andre aktører å bli hørt. Det er slitsomt og skuffende, sier Seim. Han understreker at private og stiftelser har stilt veldig opp. 


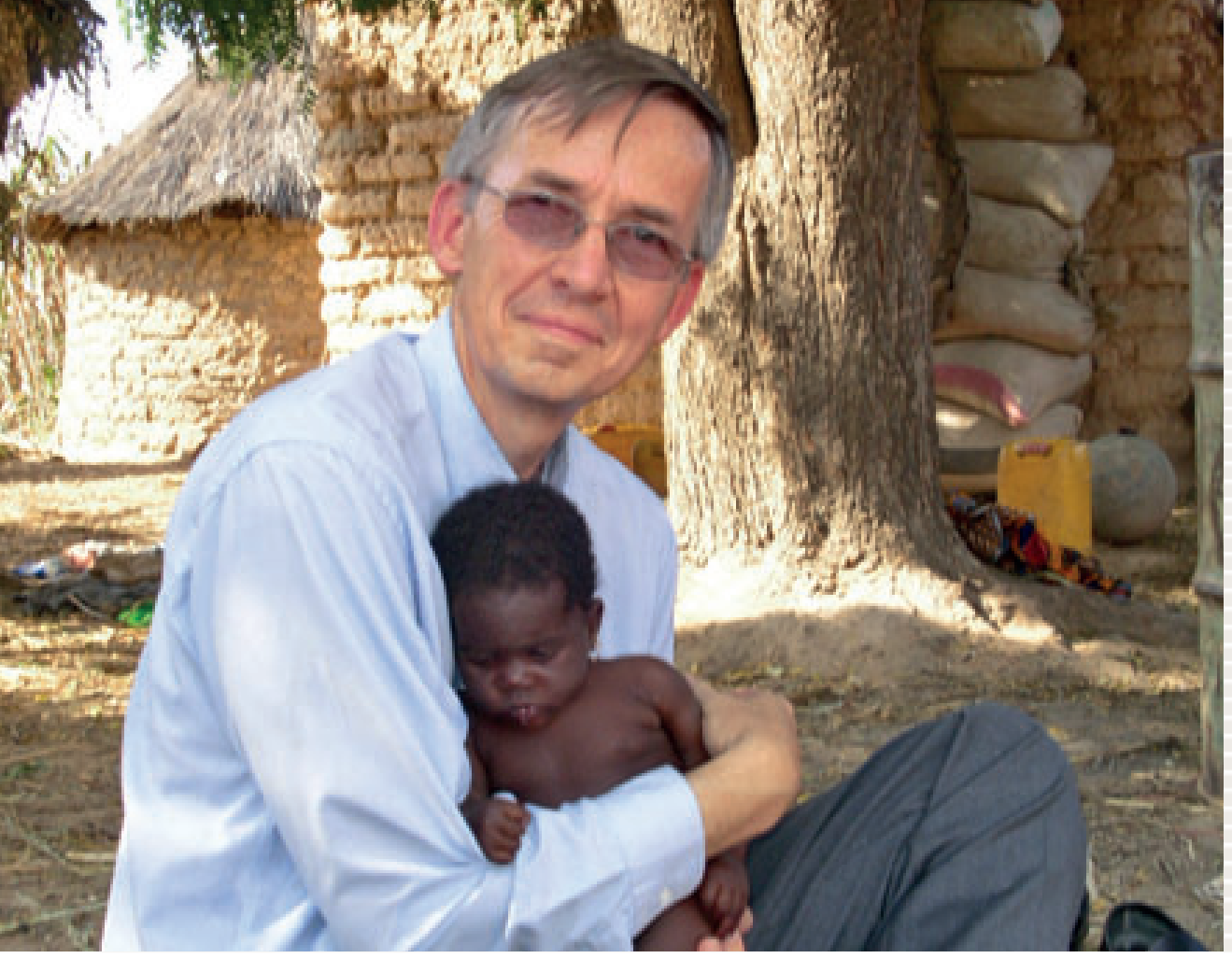

\section{$\emptyset$ delagte underliv}

Mye kan likevel oppnås med ståpåvilje, ideer og små midler. I 1997 ble HDI en pådriver i bekjempelse av den invalidiserende sykdommen lymfatisk filariasis (elefantsyke) ved bl.a. å invitere til et internasjonalt strategimøte. Programmet som ble snekret der, er det som brukes i dag. Lymfatisk filariasis affiserer ca. 120 millioner mennesker, mens én milliard bor i risikoområdene $(2,3)$. Den forårsaker fornedrelse og store lidelser, og skyldes en parasitt som spres via mygg og skader lymfesystemet. Bein, armer, bryst eller genitalia kan få kraftige hevelser, og huden kan bli tykk, hard og sprukken. For eksempel kan mannens pung bli på størrelse med en fotball og veie mange kilo.

- Slikt er ingen fordel verken $i$ arbeidseller selskapslivet. For å bryte syklusen får nå 385 millioner mennesker, hele befolkninger, en kombinasjon av medikamentene albendazol og ivermectin eller dietylkarbamazin én gang i året. Vi i HDI har bl.a. konsentrert oss om Togo, som ble det første landet i Afrika sør for Sahara til å eliminere sykdommen. Det er et eksempel på hva en liten organisasjon kan klare, sier Seim fornøyd.

Fødselsfistel er Seims siste store prosjekt. Når noen få millioner dollar - støv på kistebunnen - kunne utrydde guineaorm, var det naturlig å spørre seg: Kunne man oppnå like gode resultater med noe som ikke er biologisk utryddbart, ved å jobbe på samme måte?

- Fødselsfistel kom opp som forslag på et styremøte i det amerikanske HDI, og siden har vi jobbet med det. Ikke uten motstand. Men altså; nærmere en halv million kvinner dør i fødsel hvert år. Det er som om en fullsatt jumbojet styrtet i døden flere ganger daglig året rundt - helt absurde tall, sier Seim. Han blir oppriktig opprørt og engasjert hver gang han nevner et stort tall. Og det er ofte.

Mange av dødsfallene skyldes blokkert fødsel, der barnet sitter fast til det dør, og mor dør.

- Der kvinnen overlever, blir ofte vevet mellom skjede og urinblære ødelagt, fordi barnets hode klemmes mot bekkenet og stopper blodsirkulasjonen. Skjedevev er jo et delikat, fantastisk, eventyrlig vev, men det er følsomt for manglende blodtilførsel. Fødselsfistel er en forferdelig komplikasjon. Det medfører ukontrollert og konstant urinlekkasje, vond lukt og total isolasjon. Familie og lokalsamfunn vil ikke ha noe med disse kvinnene å gjøre. Måten å forhindre fødselsfistel på er kirurgi - både for å redde liv og beskytte kvinnens verdighet.

Sammen med FNs befolkningsfond og den amerikanske folkehelsa (CDC) organiserte HDI et nytt internasjonalt strategimøte i 2005, og i 2008 startet HDI et prosjekt i Niger, et av verdens fattigste land.

- Vi har utdannet én frivillig kvinne og én mann i hver landsby. De har lært at solen aldri må stå opp to ganger over en kvinne i fødsel. Kvinnen må til sykehus før så skjer. Eselkjerre til nærmeste helseklinikk er en mulighet, men mobiltelefon i avsidesliggende, strømløse områder muliggjør ofte tilkalling av ambulanse. Siden mai 2008 er ingen kvinne død av blokkert fødsel i prosjektområdet Bankilare i Niger (3).

\section{Pensjonist etter $\mathbf{9 0}$}

Ifølge kolleger som har sett Anders Seim $i$ aksjon, er han like vennlig og positiv enten han sitter i møte med WHO eller rundt et bål ved en stråhytte i Afrika. $\mathrm{Og}$ han blir ofte rørt til tårer over folks innsats.

- Folk er jo folk, overalt i verden. Vi blir glade for mange av de samme tingene. Dessuten vet man ikke hvilken hytte den neste Nelson Mandela bor i, sier han. Han er betatt av naturen i Afrika, av det flate landskapet som strekker seg fra land til land og av vakre solnedganger. Etter lange dager i 50 varmegrader tar han gjerne med feltsengen ut og sover under åpen himmel i den mer behagelige nattemperaturen. Under myggnettet nyter han stjernehimmelen.

Alle som beskrev Seim for meg før vi

\section{Anders Seim}

\author{
Født i Oslo i 1948
}

- Cand.med. Universitetet i Oslo 1978

- Master of Public Health, Harvard 1988

- Spesialist i allmennmedisin 1986-07

- Privatpraktiserende allmennlege, Fagerstrand 1983-01

- Grunnlegger av Health \& Development International (HDI) 1990

Foto privat

møttes nevnte først hans vennlige sinn og beskjedenhet. En venninne visste ikke at han hadde fătt Harvards høyeste utmerkelse for tidligere studenter, Alumni Award of Merit, før det ble nevnt i en tale i 60-årsdagen. Han ble også tildelt Karl Evang-prisen i 2003. Men ryktene går jo, heldigvis.

- Slike utmerkelser er rørende og hjelper $i$ arbeidet mitt. De styrker tilliten folk har til at kvakksalveren fra landet kanskje vet hva han driver med.

Landet han stadig refererer til, er altså Nesodden, der han og kona ifølge ryktene har et vidunderlig hus med egen strand og fyrlykt. Heldigvis er hagen lettstelt, for fritid er mangelvare. Seims bursdagsgave til seg selv var at han ikke lenger trenger å jobbe $i$ helgene og at han skal ha like mye ferie som sine barn. En pensjonisttilværelse er ikke nært forestående.

- Jeg har jobbet i 30 år. De neste 30 skal jeg ha fri i helger og ferier, og etter det skal jeg nyte en lang og god pensjonisttilværelse, ler han. Første mål nå er å få publisert en artikkel om fistelprosjektet i et internasjonalt tidsskrift. Men jeg har en gammel seilbåt som jeg lengter etter å reise på tur langs norskekysten med, og så er det hyggelig å gå på ski, sier Seim. Men denne dagen, etter vår tre timer lange ettermiddagssamtale, blir det verken båttur eller skitur. - I kveld skal jeg på kurs.

- Kurs?

- Jeg skal lære meg å synge.

\section{Eline Feiring}

eline.feiring@legeforeningen.no Tidsskriftet

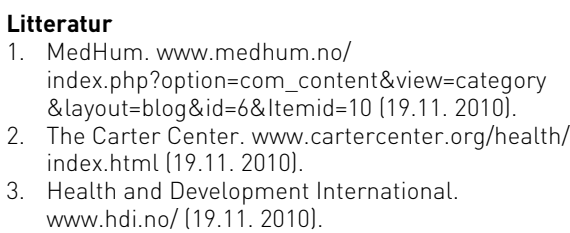

